appreciating diverse cultural perspectives that contemporary youth offer. Overall, the book offers practical examples of interdisciplinary research for designing empirical studies using both qualitative and quantitative approaches. Beginning researchers will find this book a helpful resource of approaches and methodologies that are well-defined and explained. It also offers researchers interested in these topics suggestions for issues that need further research. It provides a contemporary critical analysis of how youth are creating "new mental spaces" in negotiating local and global identities. These are important discoveries for all of us who work with youth, and would certainly help in improving social and educational immigration policies and practices.

\title{
XIIIth World Congress of Comparative Education Societies
}

The XIIIth World Congress of Comparative Education Societies, convened by the WCCES in conjunction with the International Association for Intercultural Education (IAIE) took place in Sarajevo, Bosnia and Herzegovina from September 3-7, 2007. Over 600 delegates from some 74 countries participated. The theme of the Congress was "Living Together: Education and Intercultural Dialogue.” The program included 4 keynote addresses, 15 parallel sessions in which papers relating to one or more of 13 thematic groups were presented, 7 seminars and one workshop on "Education for Peace in Bosnia and Herzegovina" sponsored by Education for Peace International and the EPI Balkans group.

This was an excellent Congress with papers of high quality. The hosts did everything they could to welcome participants to the exciting and beautiful city of Sarajevo and to help meet delegates' every need. Adila Kreso and her Congress team are to be congratulated on a most successful meeting.

This Congress marked the end of the very successful three-year term of Mark Bray as President of the WCCES. In the closing ceremonies, participants bade adieu to Mark and welcomed the new President, Crain Soudien from the University of Cape Town, South Africa.

The Turkish Comparative Education Society will prepare a formal proposal to host the XIVth World Congress in Instanbul in 2010.

Next page, pictures taken at the WCCES Congress and at the book's launching in Sarajevo, September, 2007. 


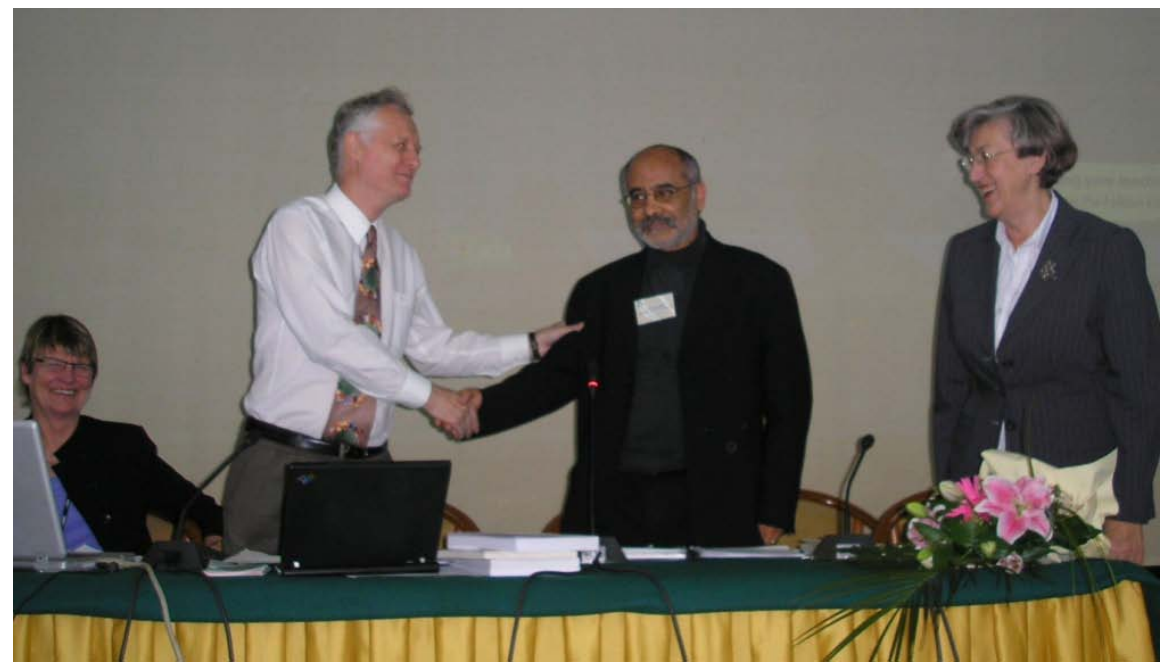

Outgoing WCCES President Mark Bray greets his successor, Crain Soudien; Secretary General, Christine Fox and WCCES Congress Chair, Adila Kreso offer congratulations.

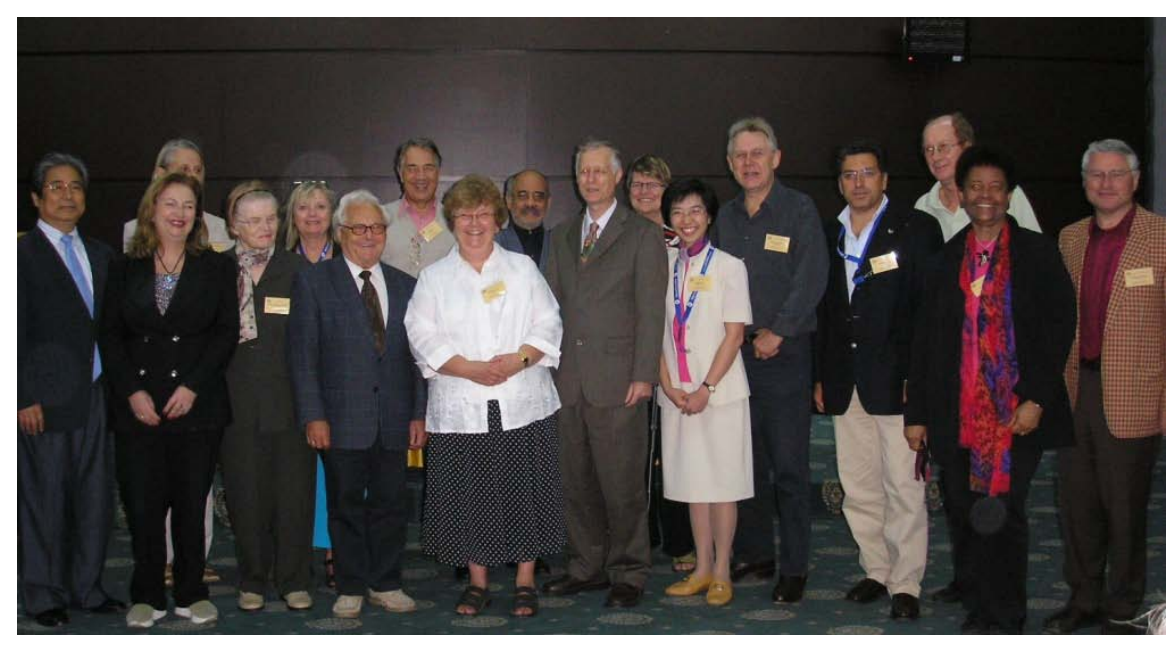

Group picture of the authors of Common Interests, Uncommon Goals. Histories of the World Council of Comparative Education Societies and its Members. 